\title{
Usulan Strategi Perawatan Excavator Menggunakan Metode RCM, Age Replacement dan RCS
}

\author{
Dio Aldri ${ }^{1 *}$, Asep Endih Nurhidayat ${ }^{2}$ \\ ${ }^{1,2}$ Program Studi Teknik Industri, Universitas Indraprasta PGRI Jakarta
}

*Corresponding author: aldri192.d@gmail.com

\section{ARTICLE INFORMATION}

Received: 29 Juli 2021

Revised: 06 Agustus 2021

Accepted: 09 Agustus 2021

Available online: 28 September 2021

\section{KEYWORDS}

Maintenance Strategy

Reliability Centered Maintenance

Reliability Centered Spares

Age Replacement

MTTF

\begin{abstract}
A B S T R A K
Tujuan dalam penelitian ini ialah penetapan strategi, waktu, kebutuhan suku cadang, biaya serta upaya untuk merumuskan usulan perbaikan dari tiap komponen kritis guna melakukan perawatan unit 320GC belum ditentukan secara spesifik. Dengan metode $\mathrm{RCM}$, age replacement dan RCS, data yang telah diolah dan dianalisis menghasilkan simpulan antara lain strategi perawatan yang tepat adalah schedule discard task. Waktu yang tepat untuk perawatan dan kebutuhan parts per tahun pada HEX-004 adalah elementfuel pada 463 jam dan 20 unit, seal gp-duo cone pada 882 jam dan 12 unit, serta valve gpsol pada 1025 jam dan 11 unit. Pada HEX-012 element-fuel pada 472 jam dan 21 unit, valve gp-sol pada 896 jam dan 12 unit, serta sensor as-level pada 1136 jam dan 10 unit. Total penghematan dari strategi yang diusulkan sebesar \$290,47 atau Rp 4.088.024,21 per jam. Usulan perbaikan pada seal gp-duo cone dengan mengecek oli final drive dengan Scheduled Oil Sampling, element-fuel dengan menjaga kebersihan fuel yang akan diisikan ke tangki bahan bakar sesuai standar ISO4406:2021, serta valve gp-sol dan sensor as-level adalah mengecek active event pada memory Electronic Control Module.
\end{abstract}

\section{INTRODUCTION}

Indonesia merupakan salah satu negara pengekspor batubara terbesar di dunia. Di tahun 2019 produksi batubara Indonesia sebesar 610 juta ton atau meningkat 9,52\% dari tahun sebelumnya dan melebihi target produksi 2019 yaitu sebesar 489 juta ton [1]. Batubara menyumbang devisa tertinggi berdasarkan komoditas pada tahun 2019 dengan raihan sebesar 21,7 miliar Dollar Amerika Serikat atau unggul sekitar $17,9 \%$ dibanding sektor pariwisata yang menyumbang 18,4 miliar Dollar Amerika Serikat [2] Potensi besar di sektor pertambangan batubara tersebut memicu peningkatan permintaan alat berat di Indonesia. Di tahun 2019 jumlah kebutuhan alat berat sebesar 129.150 unit untuk semua sektor, sedangkan jumlah ketersediaan alat yang ada berkisar 54.640 unit dan proyeksi di tahun 2020 berkisar 68.631 unit. Hal tersebut menjadikan potensi bisnis di sektor penjualan alat berat ini masih besar [3]. Melihat potensi tersebut PT. XYZ merilis excavator 320GC. Produk alat berat Caterpillar dipilih karena mempunyai reputasi global yang sangat baik dan mempunyai sebaran pasar terbesar di dunia dengan pangsa pasar sebesar 31\% [4].

Salah satu bentuk layanan purna jual yang ditawarkan oleh PT. XYZ ialah solusi perawatan terintegrasi pada seluruh unit. Pemeliharaan (maintenance) didefinisikan sebagai pekerjaan menjaga sesuatu dalam kondisi yang tepat [5]. Tujuan dari fungsi ini adalah untuk melestarikan aset atau kemampuan aset untuk menghasilkan sesuatu dengan aman dan ekonomis. Pemeliharaan juga bisa dikaitkan dengan serangkaian tindakan yang dilakukan pada suatu objek guna mempertahankannya dalam kondisi tertentu atau untuk mengembalikan pada keadaan yang telah ditentukan [6]. Penentuan strategi perawatan dari masing-masing unit pada dasarnya telah terstandarisasi dan dikontrol oleh PT. XYZ, tetapi kurangnya pemahaman mengenai strategi perawatan yang sesuai dengan karakteristik unit, maka seringkali para pelanggan menunggu unitnya sampai breakdown. Hal tersebut juga dialami oleh unit 320GC, khususnya di area Kalimantan Timur. Dalam manajemen pemeliharaan (maintenance management), strategi mengacu kepada pemilihan metode atau cara taktis guna mengelola aset fisik tertentu. Keputusan untuk menggunakan metode pemeliharaan preventif atau prediktif yang sering disebut sebagai "strategi perawatan" untuk dapat diterapkan pada segala peralatan yang digunakan. Strategi sebaiknya sederhana karena pada kenyataannya, banyak dari strategi yang 
sukses hanya sekadar panduan yang tidak rumit ataupun aturan sederhana [7].

Reliability atau keandalan teknik adalah fungsi waktu. Keandalan teknik tergantung pada kondisi yang dinyatakan. Pentingnya keandalan dalam arti rekayasa adalah bahwa itu adalah parameter teknik seperti yang lain, seperti efisiensi, daya atau apapun [8]. Metode Reliability Centered Maintenance (RCM) digunakan menentukan jenis komponen kritis pada unit 320GC. Metode RCM juga digunakan dalam penyusunan strategi perawatan yang tepat sesuai tingkat kekritisan komponen berdasarkan data yang telah dikumpulkan. Dalam reliability dikenal istilah kurva bathtub hazard rate. Kurva disebut kurva bathtub hazard rate karena menyerupai bentuk bak mandi. Kurva terbagi atas tiga periode yakni periode burn-in, masa manfaat, dan periode keausan [9].

Metode age replacement digunakan untuk menentukan waktu yang tepat untuk melakukan perawatan berdasarkan data kerusakan tiap komponen. Dalam metode age replacement terdapat dua parameter pengukuran utama yaitu MTTF dan MTTR. MTTF adalah metrik kuantitatif yang biasa digunakan untuk menilai keandalan sistem atau produk yang tidak dapat diperbaiki [10]. MTTF ialah hubungan total waktu operasi dari satu set suku cadang yang tak dapat diperbaiki dengan jumlah total kegagalan fungsi yang terdeteksi pada suku cadang di periode yang diamati. MTTR ialah hubungan antara total waktu intervensi korektif dalam sebuah set item dengan kegagalan, dan jumlah total kegagalan terdeteksi pada suku cadang dalam periode yang diamati [11].

Metode Reliability Centered Spares (RCS) digunakan dalam melakukan perhitungan kebutuhan suku cadang untuk unit 320GC yang perlu disediakan untuk mendukung proses pemeliharaan. Suku cadang perlu dievaluasi dalam hal biaya dan kekritisan. Kekritisan juga dapat dianalisis dengan menggunakan kriteria antara lain

1. Sangat kritis: bagian yang mutlak penting untuk pengoperasian peralatan.

2. Cukup kritis: bagian yang jika tidak tersedia akan memiliki sedikit sampai dengan sedang berpengaruh pada pengoperasian peralatan.

3. Kekritisan rendah: bagian yang tidak mutlak penting untuk pengoperasian perlengkapan [12].

\section{METHOD}

Penelitian dilakukan dengan studi literatur dan wawancara. Studi literatur dilkukan dengan mengkaji sistem excavator 320GC dari referensi digital yang diperoleh dari perusahaan. Wawancara dilakukan untuk mendapatkan informasi tambahan terkait produktivitas unit, harga acuan pasar batubara. Penulis mengumpulkan data primer yang berupa data komponen terpasang, harga suku cadang di pasaran dan sistem kerjanya, data waktu dan total kerusakan komponen, daftar suku cadang yang bermasalah pada unit, populasi unit di area penelitian, dan data terkait profil perusahaan. Data sekunder berupa referensi tambahan seperti tabel fungsi gamma, dan artikel dari penelitian terdahulu. Metode yang digunakan dalam penelitian ini antara lain menggunakan metode Reliability Centered Maintenance (RCM), metode age replacement, dan metode Reliability Centered Spares (RCS). Flow chart penelitian ini dapat digambarkan sebagai berikut.

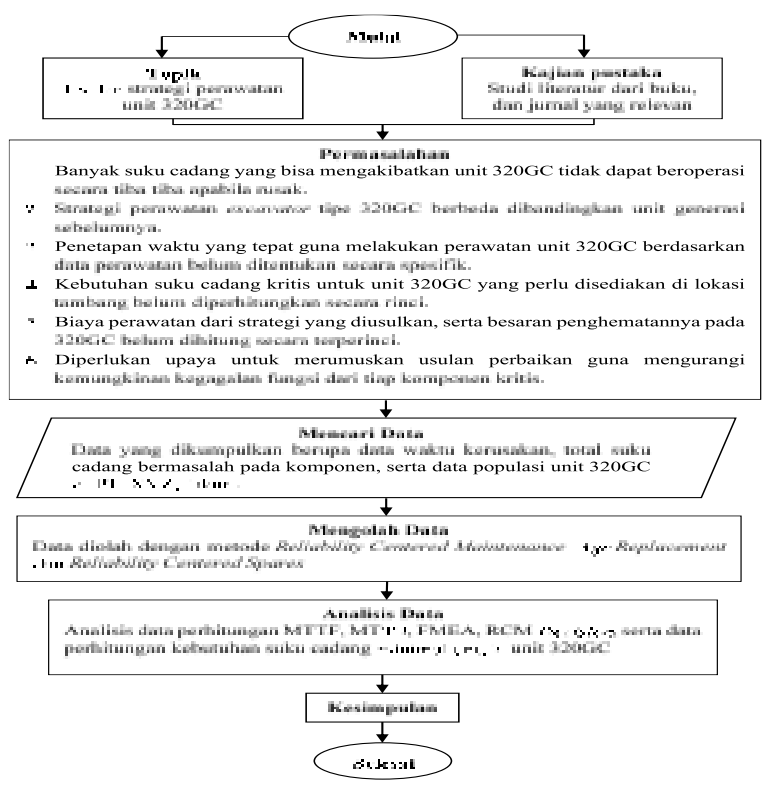

Gambar 1. Flowchart Penelitian

\section{RESULTS AND DISCUSSION}

\section{Data Availability Unit}

Dari pengumpulan data diperoleh data availability dari tiap unit 320GC yang berada di area pertambangan di Kalimantan Timur sebagai berikut:

Tabel 1. Data Availability Unit 320GC di PT XYZ

\begin{tabular}{cccccc}
\hline Field ID & $\begin{array}{c}\text { Avail } \\
\text { ability } \\
(\%)\end{array}$ & $\begin{array}{c}\text { Target } \\
(\%)\end{array}$ & Field ID & $\begin{array}{c}\text { Avail } \\
\text { ability } \\
(\%)\end{array}$ & $\begin{array}{c}\text { Target } \\
(\%)\end{array}$ \\
\hline HEX-001 & 88 & 85 & HEX-012 & 83 & 85 \\
HEX-002 & 89 & 85 & HEX-013 & 87 & 85 \\
HEX-003 & 98 & 85 & HEX-014 & 96 & 85 \\
HEX-004 & 80 & 85 & HEX-015 & 90 & 85 \\
HEX-005 & 93 & 85 & HEX-016 & 91 & 85 \\
HEX-006 & 89 & 85 & HEX-017 & 89 & 85 \\
HEX-007 & 86 & 85 & HEX-018 & 92 & 85 \\
HEX-008 & 92 & 85 & HEX-019 & 88 & 85 \\
HEX-009 & 92 & 85 & HEX-020 & 96 & 85 \\
HEX-010 & 91 & 85 & HEX-021 & 92 & 85 \\
HEX-011 & 98 & 85 & & & \\
\hline
\end{tabular}

Dari tabel di atas diketahui bahwa unit HEX-004 dan HEX-012 mempunyai availability di bawah target. Oleh karena itu unit yang menjadi fokus dalam penelitian ini adalah HEX-004 dan HEX-012. 


\section{Data Komponen Kritis}

Komponen kritis dari exavator dengan kode HEX-004 adalah sebagai berikut.

Tabel 2. Data Komponen Kritis HEX-004

\begin{tabular}{|c|c|c|c|c|}
\hline Rank & System & Subsystem & $\begin{array}{c}\text { Part } \\
\text { Description } \\
\end{array}$ & $\begin{array}{c}\text { Event } \\
\text { Reported }\end{array}$ \\
\hline 1 & $\begin{array}{c}\text { Fuel } \\
\text { System }\end{array}$ & Filter $G p$ & $\begin{array}{l}\text { Element- } \\
\text { Fuel }\end{array}$ & 27 \\
\hline 2 & $\begin{array}{c}\text { Fuel } \\
\text { System }\end{array}$ & $\begin{array}{c}\text { Pump Gp-Fuel } \\
\text { Injection }\end{array}$ & $\begin{array}{l}\text { Injector } \\
\text { Gp-Fuel }\end{array}$ & 4 \\
\hline 3 & Final Drive & Drive Gp-Final & $\begin{array}{l}\text { Seal Gp- } \\
\text { Duo Cone }\end{array}$ & 16 \\
\hline 4 & $\begin{array}{l}\text { Control } \\
\text { Valve }\end{array}$ & $\begin{array}{c}\text { Valve Gp-Main } \\
\text { Control }\end{array}$ & $\begin{array}{l}\text { Valve Gp- } \\
\quad \text { Sol }\end{array}$ & 14 \\
\hline 5 & $\begin{array}{l}\text { Lube } \\
\text { System }\end{array}$ & Pan Gp-Oil & $\begin{array}{l}\text { Gasket- } \\
\text { Sump }\end{array}$ & 9 \\
\hline 6 & $\begin{array}{l}\text { Hydraulic } \\
\text { Tank }\end{array}$ & $\begin{array}{l}\text { Tank \& Filter } \\
\text { Gp-Hydraulic }\end{array}$ & $\begin{array}{l}\text { Sensor Gp- } \\
\text { Temp }\end{array}$ & 1 \\
\hline 7 & Electrical & Wiring $G p$ & $\begin{array}{c}\text { Switch As- } \\
\text { Limit }\end{array}$ & 1 \\
\hline
\end{tabular}

Pada HEX-012 diperoleh data komponen kritis sebagai berikut

Tabel 3. Data Komponen Kritis HEX-012

\begin{tabular}{|c|c|c|c|c|}
\hline Rank & System & Subsystem & $\begin{array}{c}\text { Part } \\
\text { Description }\end{array}$ & $\begin{array}{c}\text { Event } \\
\text { Reported }\end{array}$ \\
\hline 1 & $\begin{array}{c}\text { Fuel } \\
\text { System }\end{array}$ & Filter $G p$ & $\begin{array}{l}\text { Element- } \\
\text { Fuel }\end{array}$ & 29 \\
\hline 2 & $\begin{array}{c}\text { Fuel } \\
\text { System }\end{array}$ & $\begin{array}{c}\text { Pump Gp-Fuel } \\
\text { Priming }\end{array}$ & $\begin{array}{l}\text { Sensor As- } \\
\text { Level }\end{array}$ & 12 \\
\hline 3 & $\begin{array}{l}\text { Fuel } \\
\text { System }\end{array}$ & Filter $G p$ & $\begin{array}{l}\text { Sensor Gp- } \\
\quad \text { Press }\end{array}$ & 9 \\
\hline 4 & $\begin{array}{c}\text { Fuel } \\
\text { System }\end{array}$ & $\begin{array}{l}\text { Pump Gp-Fuel } \\
\text { Injection }\end{array}$ & $\begin{array}{l}\text { Injector } \\
\text { Gp-Fuel }\end{array}$ & 5 \\
\hline 5 & $\begin{array}{l}\text { Control } \\
\text { Valve }\end{array}$ & $\begin{array}{c}\text { Valve Gp-Main } \\
\text { Control }\end{array}$ & $\begin{array}{l}\text { Valve Gp- } \\
\quad \text { Sol }\end{array}$ & 15 \\
\hline 6 & $\begin{array}{l}\text { Cooling } \\
\text { System }\end{array}$ & $\begin{array}{c}\text { Radiator \& Hyd } \\
\text { Oil Cooler Gp }\end{array}$ & $\begin{array}{c}\text { Fan As- } \\
\text { Axial }\end{array}$ & 7 \\
\hline 7 & Electrical & Wiring $G p$ & Switch As & 2 \\
\hline
\end{tabular}

\section{Diagram Pareto Data Komponen Kritis}

Persentase kumulatif dari kejadian kegagalan fungsi komponen kritis pada excavator dengan kode HEX-004 sebagai berikut.

Tabel 4. Data Komponen Kritis HEX-004

\begin{tabular}{ccccc}
\hline Rank & Part Description & $\begin{array}{c}\text { Event } \\
\text { Reported }\end{array}$ & $\%$ & $\begin{array}{c}\% \\
\text { Kum }\end{array}$ \\
\hline 1 & Element-Fuel & 27 & $38 \%$ & $38 \%$ \\
2 & Seal Gp-Duo Cone & 16 & $22 \%$ & $60 \%$ \\
3 & Valve Gp-Sol & 14 & $19 \%$ & $79 \%$ \\
4 & Gasket-Sump & 9 & $13 \%$ & $92 \%$ \\
5 & Injector Gp-Fuel & 4 & $6 \%$ & $97 \%$ \\
6 & Switch As-Limit & 1 & $1 \%$ & $99 \%$ \\
7 & Sensor Gp-Temp & 1 & $1 \%$ & $100 \%$ \\
& Total Event Reported & 72 & $100 \%$ & \\
\hline \multicolumn{7}{r}{}
\end{tabular}

Diagram pareto data komponen kritis HEX-004 adalah sebagai berikut

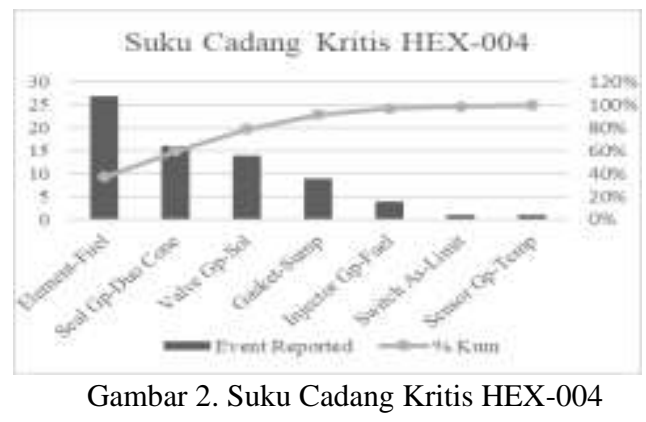

Persentase kumulatif dari kejadian kegagalan fungsi komponen kritis pada excavator dengan kode HEX-012 sebagai berikut

Tabel 5. Data Komponen Kritis HEX-012

\begin{tabular}{ccccc}
\hline Rank & Part Description & $\begin{array}{c}\text { Event } \\
\text { Reported }\end{array}$ & $\%$ & $\%$ Kum \\
\hline 1 & Element-Fuel & 29 & $37 \%$ & $37 \%$ \\
2 & Valve Gp-Sol & 15 & $19 \%$ & $56 \%$ \\
3 & Sensor As-Level & 12 & $15 \%$ & $71 \%$ \\
4 & Sensor Gp-Press & 9 & $11 \%$ & $82 \%$ \\
5 & Fan As-Axial & 7 & $9 \%$ & $91 \%$ \\
6 & Injector Gp-Fuel & 5 & $6 \%$ & $97 \%$ \\
7 & Switch As & 2 & $3 \%$ & $100 \%$ \\
Total Event Reported & 79 & $100 \%$ & \\
\hline
\end{tabular}

Diagram pareto data komponen kritis HEX-012 adalah sebagai berikut

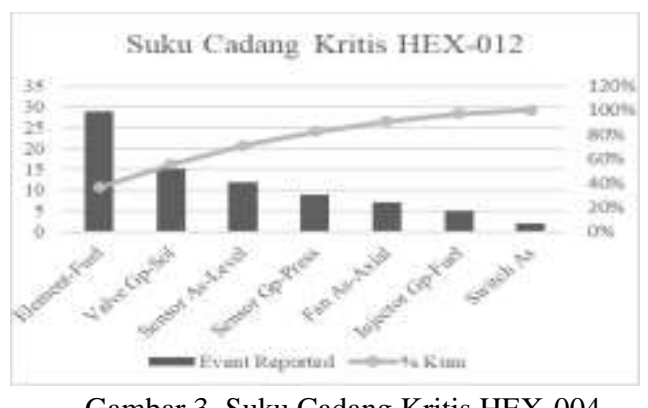

Gambar 3. Suku Cadang Kritis HEX-004

Dari diagram pareto diperoleh kesimpulan bahwasanya terdapat 4 komponen kritis pada HEX-004 yaitu elementfuel, seal gp-duo dan valve gp-sol. Sedangkan pada HEX012 terdapat 4 komponen kritis yaitu element-fuel, valve gp-sol, dan sensor as level.

\section{Penentuan Time To Repair dan Time To Failure Komponen Kritis}

Time To Repair (TTR) merupakan waktu yang diperlukan untuk memperbaiki komponen. Time To Failure (TTF) merupakan interval waktu antar kerusakan yang dihitung dari selisih antara waktu kerusakan komponen yang telah selesai diperbaiki dengan waktu kerusakan komponen berikutnya. Komponen element-fuel pada excavator dengan kode HEX-004 memiliki nilai TTR dan TTF sebagai berikut.

Tabel 6. Data TTR dan TTF Komponen Element-Fuel HEX-004

\begin{tabular}{cccc}
\hline No & Date & TTR & TTF \\
\hline 1 & 30 Jan 19 & 7 & \\
2 & 25 Feb 19 & 10 & 513 \\
3 & 23 Mar 19 & 11 & 516 \\
4 & 17 Apr 19 & 13 & 501 \\
5 & 13 Mei 19 & 11 & 514
\end{tabular}




\begin{tabular}{cccc}
6 & 8 Jun 19 & 4 & 531 \\
7 & 4 Jul 19 & 10 & 524 \\
8 & 31 Jul 19 & 12 & 527 \\
9 & 25 Agu 19 & 7 & 516 \\
10 & 20 Sep 19 & 16 & 504 \\
11 & 16 Okt 19 & 6 & 526 \\
12 & 10 Nov 19 & 15 & 510 \\
13 & 5 Des 19 & 9 & 489 \\
14 & 31 Des 19 & 7 & 530 \\
15 & 26 Jan 20 & 3 & 511 \\
16 & 21 Feb 20 & 17 & 519 \\
17 & 18 Mar 20 & 18 & 516 \\
18 & 13 Apr 20 & 5 & 523 \\
19 & 9 Mei 20 & 8 & 526 \\
20 & 4 Jun 20 & 7 & 521 \\
21 & 1 Jul 20 & 5 & 529 \\
22 & 26 Jul 20 & 4 & 512 \\
23 & 21 Agu 20 & 9 & 516 \\
24 & 16 Sep 20 & 14 & 515 \\
25 & 11 Okt 20 & 9 & 499 \\
26 & 6 Nov 20 & 13 & 522 \\
27 & 2 Des 20 & 2 & 528 \\
\hline
\end{tabular}

Komponen seal gp-duo cone pada excavator dengan kode HEX-004 memiliki nilai TTR dan TTF sebagai berikut.

Tabel 7. Data TTR dan TTF Komponen Seal Gp-Duo Cone

\begin{tabular}{cccc}
\multicolumn{3}{c}{ HEX-004 } \\
\hline No & Date & TTR & TTF \\
\hline 1 & 4 Jan 19 & 16 & \\
2 & 21 Feb 19 & 16 & 960 \\
3 & 10 Apr 19 & 16 & 947 \\
4 & 28 Mei 19 & 12 & 962 \\
5 & 15 Jul 19 & 16 & 963 \\
6 & 31 Agu 19 & 10 & 950 \\
7 & 17 Okt 19 & 15 & 929 \\
8 & 4 Des 19 & 17 & 967 \\
9 & 22 Jan 20 & 17 & 977 \\
10 & 11 Mar 20 & 17 & 975 \\
11 & 29 Apr 20 & 17 & 979 \\
12 & 15 Jun 20 & 15 & 949 \\
13 & 3 Agu 20 & 11 & 968 \\
14 & 21 Sep 20 & 14 & 984 \\
15 & 9 Nov 20 & 13 & 977 \\
16 & 28 Des 20 & 14 & 978 \\
\hline
\end{tabular}

Komponen valve gp-sol pada excavator dengan kode HEX-004 memiliki nilai TTR dan TTF sebagai berikut.

Tabel 8. Data TTR dan TTF Komponen Valve Gp-Sol HEX-004

\begin{tabular}{cccc}
\hline No & Date & TTR & TTF \\
\hline 1 & 12 Jan 19 & 16 & \\
2 & 8 Mar 19 & 19 & 1105 \\
3 & 2 Mei 19 & 16 & 1102 \\
4 & 27 Jun 19 & 20 & 1115 \\
5 & 20 Agu 19 & 15 & 1067 \\
6 & 15 Okt 19 & 17 & 1120 \\
7 & 9 Des 19 & 18 & 1106 \\
8 & 2 Feb 20 & 18 & 1108 \\
9 & 29 Mar 20 & 18 & 1110 \\
10 & 23 Mei 20 & 15 & 1114 \\
11 & 16 Jul 20 & 19 & 1080 \\
12 & 10 Sep 20 & 13 & 1119 \\
13 & 4 Nov 20 & 17 & 1099 \\
14 & 30 Des 20 & 19 & 1104 \\
\hline
\end{tabular}

Komponen element-fuel pada excavator dengan kode HEX-012 memiliki nilai TTR dan TTF sebagai berikut

Tabel 9. Data TTR dan TTF Komponen Element-Fuel HEX-012

\begin{tabular}{cccc}
\hline No & Date & TTR & TTF \\
\hline 1 & 8 Jan 19 & 12 & \\
2 & 2 Feb 19 & 13 & 508 \\
3 & 28 Feb 19 & 13 & 514 \\
4 & 24 Mar 19 & 6 & 492 \\
5 & 19 Apr 19 & 11 & 517 \\
6 & 15 Mei 19 & 10 & 515 \\
7 & 9 Jun 19 & 9 & 503 \\
8 & 5 Jul 19 & 12 & 512 \\
9 & 30 Jul 19 & 11 & 508 \\
10 & 25 Agu 19 & 12 & 513 \\
11 & 19 Sep 19 & 10 & 508 \\
12 & 14 Okt 19 & 12 & 506 \\
13 & 9 Nov 19 & 10 & 508 \\
14 & 4 Des 19 & 12 & 505 \\
15 & 29 Des 19 & 12 & 510 \\
16 & 24 Jan 20 & 14 & 515 \\
17 & 18 Feb 20 & 10 & 494 \\
18 & 14 Mar 20 & 12 & 508 \\
19 & 9 Apr 20 & 9 & 512 \\
20 & 4 Mei 20 & 12 & 504 \\
21 & 30 Mei 20 & 11 & 517 \\
22 & 25 Jun 20 & 13 & 511 \\
23 & 20 Jul 20 & 13 & 503 \\
24 & 14 Agu 20 & 11 & 510 \\
25 & 9 Sep 20 & 9 & 514 \\
26 & 5 Okt 20 & 10 & 517 \\
27 & 30 Okt 20 & 12 & 514 \\
28 & 25 Nov 20 & 12 & 510 \\
29 & 21 Des 20 & 14 & 518 \\
\hline & & &
\end{tabular}

Komponen valve gp-sol pada excavator dengan kode HEX-012 memiliki nilai TTR dan TTF sebagai berikut

Tabel 10. Data TTR dan TTF Komponen Valve Gp-Sol HEX-012

\begin{tabular}{cccc}
\hline No & Date & TTR & TTF \\
\hline 1 & 3 Jan 19 & 19 & \\
2 & 20 Feb 19 & 20 & 967 \\
3 & 9 Apr 19 & 15 & 954 \\
4 & 27 Mei 19 & 17 & 959 \\
5 & 15 Jul 19 & 10 & 971 \\
6 & 31 Agu 19 & 15 & 947 \\
7 & 18 Okt 19 & 18 & 963 \\
8 & 5 Des 19 & 12 & 956 \\
9 & 20 Jan 20 & 14 & 930 \\
10 & 9 Mar 20 & 19 & 970 \\
11 & 26 Apr 20 & 16 & 960 \\
12 & 14 Jun 20 & 13 & 978 \\
13 & 1 Agu 20 & 18 & 969 \\
14 & 19 Sep 20 & 17 & 982 \\
15 & 7 Nov 20 & 19 & 962 \\
\hline
\end{tabular}

Komponen sensor as-level pada excavator dengan kode HEX-012 memiliki nilai TTR dan TTF sebagai berikut

Tabel 11. Data TTR dan TTF Sensor As-Level HEX-012

\begin{tabular}{cccc}
\hline No & Date & TTR & TTF \\
\hline 1 & 18 Jan 19 & 10 & \\
2 & 22 Mar 19 & 12 & 1249 \\
3 & 23 Mei 19 & 9 & 1248
\end{tabular}

Dio Aldri 


$\begin{array}{cccc}4 & \text { 22 Jul 19 } & 14 & 1203 \\ 5 & \text { 24 Sep 19 } & 12 & 1271 \\ 6 & \text { 25 Nov 19 } & 12 & 1247 \\ 7 & \text { 27 Jan 20 } & 14 & 1257 \\ 8 & \text { 29 Mar 20 } & 12 & 1241 \\ 9 & \text { 30 Mei 20 } & 9 & 1252 \\ 10 & \text { 1 Agu 20 } & 13 & 1260 \\ 11 & \text { 4 Okt 20 } & 12 & 1261 \\ 12 & \text { 5 Des 20 } & 15 & 1244\end{array}$

\section{Perhitungan Mean Time To Failure (MTTF) dan Mean} Time To Repair (MTTR)

Sebelum menghitung MTTF dan MTTR, maka terlebih dahulu melakukan pengujian distribusi terhadap waktu failure (TTF) dan waktu repair (TTR) masing-masing komponen kritis. Pengujian ini dilakukan dengan menggunakan software Minitab 19 dengan parameter uji nilai Anderson Darling Test (AD) dan $P$ value. TTF maupun TTR disebut mengikuti distribusi tertentu bilamana nilai Anderson Darling-nya adalah terkecil di antara yang lain dan $P$ value $>\alpha$. Pada pengujian ini nilai $\alpha=0,05$ atau $5 \%$. Berikut tabel pengujian distribusi dari waktu repair (TTR) dari excavator dengan kode HEX-004.

Tabel 12. Pengujian Distribusi Terhadap Waktu Repair (TTR) HEX-004

\begin{tabular}{ccccc}
\hline Komponen & Distribusi & $\begin{array}{c}\text { Nilai } \\
\text { Anderson } \\
\text { Darling }\end{array}$ & $\begin{array}{c}P \text { - } \\
\text { Value }\end{array}$ & $\begin{array}{c}\text { Distribusi } \\
\text { Terpilih }\end{array}$ \\
\hline Element- & Normal & 0,234 & 0,773 & \\
Fuel & Weibull & 0,153 & $>0,250$ & Weibull \\
& Lognormal & 0,388 & 0,362 & \\
\hline \multirow{5}{*}{ Seal Gp- } & Normal & 0,712 & 0,05 & \\
Euo Cone & Weibull & 5,419 & $<0,003$ & Weibull \\
& Lognormal & 0,654 & 0,08 & \\
\hline \multirow{4}{*}{ Valve Gp- } & Normal & 0,324 & 0,019 & \\
Sol & Exponential & 5,124 & $<0,484$ & \\
& Weibull & 0,281 & $>0,250$ & Weibull \\
& Lognormal & 0,397 & 0,32 & \\
\hline
\end{tabular}

Berikut tabel pengujian distribusi dari waktu repair (TTR) dari excavator dengan kode HEX-012.

Tabel 13. Pengujian Distribusi Terhadap Waktu Repair (TTR) HEX-012

\begin{tabular}{|c|c|c|c|c|}
\hline Komponen & Distribusi & $\begin{array}{c}\text { Nilai } \\
\text { Anderson } \\
\text { Darling }\end{array}$ & $\begin{array}{c}P- \\
\text { Value }\end{array}$ & $\begin{array}{c}\text { Distribusi } \\
\text { Terpilih }\end{array}$ \\
\hline \multirow{4}{*}{$\begin{array}{l}\text { Element- } \\
\text { Fuel }\end{array}$} & Normal & 0,883 & 0,021 & \multirow{4}{*}{ Weibull } \\
\hline & Exponential & 9,815 & $<0,003$ & \\
\hline & Weibull & 0,723 & 0,053 & \\
\hline & Lognormal & 1,252 & $<0,005$ & \\
\hline \multirow{4}{*}{$\begin{array}{l}\text { Valve } G p- \\
\quad \text { Sol }\end{array}$} & Normal & 0,346 & 0,433 & \multirow{4}{*}{ Weibull } \\
\hline & Exponential & 4,707 & $<0,003$ & \\
\hline & Weibull & 0,313 & $>0,250$ & \\
\hline & Lognormal & 0,495 & 0,182 & \\
\hline \multirow{2}{*}{$\begin{array}{l}\text { Sensor As- } \\
\text { Level }\end{array}$} & Normal & 0,518 & 0,149 & \multirow{2}{*}{ Weibull } \\
\hline & Exponential & 4,029 & $<0,003$ & \\
\hline
\end{tabular}

$\begin{array}{ccc}\text { Weibull } & 0,492 & 0,208 \\ \text { Lognormal } & 0,616 & 0,083\end{array}$

Kemudian ditentukan parameter masing-masing distribusi dengan menggunakan software Availability Workbench 4 dengan hasil parameter berupa parameter $\eta$, dan $\beta$. Berikut hasil perhitungan parameter dari distribusi terpilih dan nilai MTTR dari excavator dengan kode HEX-004.

Tabel 14. Parameter Distribusi Terpilih dan MTTR HEX-004

\begin{tabular}{|c|c|c|c|c|}
\hline \multirow{2}{*}{ Komponen } & \multirow{2}{*}{ Distribusi } & \multicolumn{2}{|c|}{ Parameter } & \multirow{2}{*}{ MTTR } \\
\hline & & Simbol & Nilai & \\
\hline \multirow{2}{*}{$\begin{array}{c}\text { Element- } \\
\text { Fuel }\end{array}$} & \multirow{2}{*}{ Weibull } & $\eta$ & 10,61 & \multirow{2}{*}{9,39622} \\
\hline & & $\beta$ & 2,165 & \\
\hline \multirow{2}{*}{$\begin{array}{l}\text { Seal Gp- } \\
\text { Duo Cone }\end{array}$} & \multirow{2}{*}{ Weibull } & $\eta$ & 15,77 & \multirow{2}{*}{14,714} \\
\hline & & $\beta$ & 6,845 & \\
\hline \multirow{2}{*}{$\begin{array}{l}\text { Valve Gp- } \\
\quad \text { Sol }\end{array}$} & \multirow{2}{*}{ Weibull } & $\eta$ & 18,02 & \multirow{2}{*}{17,0721} \\
\hline & & $\beta$ & 9,505 & \\
\hline
\end{tabular}

Berikut hasil perhitungan parameter dari distribusi terpilih dan nilai MTTR dari excavator dengan kode HEX-012.

Tabel 15. Parameter Distribusi Terpilih dan MTTR HEX-012

\begin{tabular}{ccccc}
\hline \multirow{2}{*}{ Komponen } & \multirow{2}{*}{ Distribusi } & \multicolumn{2}{c}{ Parameter } & \multirow{2}{*}{ MTTR } \\
\cline { 3 - 4 } & & Simbol & Nilai & \\
\hline Element- & \multirow{2}{*}{ Weibull } & $\eta$ & 12,09 & \multirow{2}{*}{11,2805} \\
Fuel & & $\beta$ & 6,632 & \\
\hline $\begin{array}{c}\text { Valve Gp- } \\
\text { Sol }\end{array}$ & \multirow{2}{*}{ Weibull } & $\eta$ & 17,4 & \multirow{2}{*}{16,1246} \\
\hline $\begin{array}{c}\text { Sensor As- } \\
\text { Level }\end{array}$ & \multirow{2}{*}{ Weibull } & $\eta$ & 5,772 & \\
\hline
\end{tabular}

Berikut tabel pengujian distribusi dari waktu kerusakan (TTF) dari excavator dengan kode HEX-004.

Tabel 16. Pengujian Distribusi Terhadap Waktu Failure (TTF) HEX-004

\begin{tabular}{ccccc}
\hline Komponen & Distribusi & $\begin{array}{c}\text { Nilai } \\
\text { Anderson } \\
\text { Darling }\end{array}$ & $\begin{array}{c}P \text { - } \\
\text { Value }\end{array}$ & $\begin{array}{c}\text { Distribusi } \\
\text { Terpilih }\end{array}$ \\
\hline Element- & Normal & 0,467 & 0,232 & \\
Fuel & Weibull & 0,269 & $>0,250$ & Weibull \\
& Lognormal & 0,498 & 0,192 & \\
\hline \multirow{4}{*}{ Seal Gp- } & Normal & 0,44 & 0,253 & \\
Euo Cone & Weibull & 0,33 & $>0,250$ & Weibull \\
& Lognormal & 0,452 & 0,235 & \\
\hline \multirow{4}{*}{ Valve Gp- } & Normal & 0,79 & 0,029 & \\
Sol & Weibull & 0,333 & $>0,250$ & Weibull \\
& Lognormal & 0,813 & 0,026 & \\
\hline
\end{tabular}

Berikut tabel pengujian distribusi dari waktu kerusakan (TTF) dari excavator dengan kode HEX-004. 
Tabel 17. Pengujian Distribusi Terhadap Waktu Failure (TTF) HEX-012

\begin{tabular}{ccccc}
\hline Komponen & Distribusi & $\begin{array}{c}\text { Nilai } \\
\text { Anderson } \\
\text { Darling }\end{array}$ & $\begin{array}{c}P- \\
\text { Value }\end{array}$ & $\begin{array}{c}\text { Distribusi } \\
\text { Terpilih }\end{array}$ \\
\hline Element- & Normal & 0,686 & 0,065 & \\
Fuel & Weibonential & 12,552 & $<0,003$ & Weibull \\
& Lognormal & 0,277 & $>0,250$ & \\
& Normal & 0,718 & 0,054 & \\
Valve Gp- & Exponential & 6,264 & 0,548 & \\
Sol & Weibull & 0,181 & $>0,003$ & Weibull \\
& Lognormal & 0,309 & 0,516 & \\
\hline \multirow{2}{*}{ Sensor As- } & Normal & 0,76 & 0,033 & \\
Level & Exponential & 4,933 & $<0,003$ & Weibull \\
& Weibull & 0,351 & $>0,250$ & \\
\hline & Lognormal & 0,786 & 0,028 & \\
\hline
\end{tabular}

Hasil perhitungan parameter dari distribusi terpilih dan nilai MTTF dari excavator dengan kode HEX-004 adalah sebagai berikut

Tabel 18. Parameter Distribusi Terpilih dan MTTF HEX-004

\begin{tabular}{|c|c|c|c|c|}
\hline \multirow{2}{*}{ Komponen } & \multirow{2}{*}{ Distribusi } & \multicolumn{2}{|c|}{ Parameter } & \multirow{2}{*}{ MTTF } \\
\hline & & Simbol & Nilai & \\
\hline \multirow{2}{*}{$\begin{array}{l}\text { Element- } \\
\text { Fuel }\end{array}$} & \multirow{2}{*}{ Weibull } & $\eta$ & 521,7 & \multirow{2}{*}{515,88} \\
\hline & & $\beta$ & 58,2 & \\
\hline \multirow{2}{*}{$\begin{array}{l}\text { Seal Gp- } \\
\text { Duo Cone }\end{array}$} & \multirow{2}{*}{ Weibull } & $\eta$ & 971,5 & \multirow{2}{*}{965,99} \\
\hline & & $\beta$ & 71,3 & \\
\hline \multirow{2}{*}{$\begin{array}{l}\text { Valve Gp- } \\
\quad \text { Sol }\end{array}$} & \multirow{2}{*}{ Weibull } & $\eta$ & 1111 & \multirow{2}{*}{1104,70} \\
\hline & & $\beta$ & 79,35 & \\
\hline
\end{tabular}

Hasil perhitungan parameter dari distribusi terpilih dan nilai MTTF dari excavator dengan kode HEX-012 adalah sebagai berikut

$\underline{\text { Tabel 19. Parameter Distribusi Terpilih dan MTTF HEX-012 }}$

\begin{tabular}{|c|c|c|c|c|}
\hline \multirow{2}{*}{ Komponen } & \multirow{2}{*}{ Distribusi } & \multicolumn{2}{|c|}{ Parameter } & \multirow{2}{*}{ MTTF } \\
\hline & & Simbol & Nilai & \\
\hline \multirow{2}{*}{$\begin{array}{l}\text { Element- } \\
\text { Fuel }\end{array}$} & \multirow{2}{*}{ Weibull } & $\eta$ & 512,5 & \multirow{2}{*}{509,59} \\
\hline & & $\beta$ & 93,22 & \\
\hline \multirow{2}{*}{$\begin{array}{l}\text { Valve Gp- } \\
\text { Sol }\end{array}$} & \multirow{2}{*}{ Weibull } & $\eta$ & 968,2 & \multirow{2}{*}{962,71} \\
\hline & & $\beta$ & 82,28 & \\
\hline \multirow{2}{*}{$\begin{array}{l}\text { Sensor As- } \\
\text { Level }\end{array}$} & \multirow{2}{*}{ Weibull } & $\eta$ & 1257 & \multirow{2}{*}{1249,87} \\
\hline & & $\beta$ & 74,13 & \\
\hline
\end{tabular}

6. Perhitungan Age Replacement

a. Perhitungan Age Replacement Element-Fuel pada HEX-004

Dengan nilai $\alpha$ sebesar 521,7, $\beta$ sebesar 58,2, MTTF sebesar 515,88, MTTR sama dengan Tf yaitu sebesar 9,40, dan Tp sebesar 1, maka nilai masing-masing $R(t p), F(t p)$, $\mathrm{M}(\mathrm{tp})$ dan $\mathrm{D}(\mathrm{tp})$ antara lain.

Tabel 20. Age Replacement Element-Fuel pada HEX-004

\begin{tabular}{ccccc}
\hline tp & $\mathrm{R}(\mathrm{tp})$ & $\mathrm{F}(\mathrm{tp})$ & $\mathrm{M}(\mathrm{tp})$ & $\mathrm{D}(\mathrm{tp})$ \\
\hline 450 & 0,999817 & 0,000183 & 2815223,514 & 0,001035933 \\
460 & 0,999342 & 0,000658 & 783571,420 & 0,001029642 \\
461 & 0,999253 & 0,000747 & 690573,322 & 0,001029393 \\
462 & 0,999153 & 0,000847 & 608782,957 & 0,001029252 \\
463 & 0,999039 & 0,000961 & 536829,617 & 0,00102923
\end{tabular}

\begin{tabular}{ccccc}
464 & 0,998911 & 0,001089 & 473512,670 & 0,001029344 \\
465 & 0,998765 & 0,001235 & 417780,153 & 0,001029609 \\
500 & 0,919096 & 0,080904 & 6376,435 & 0,001718946 \\
520 & 0,437362 & 0,562638 & 916,896 & 0,007644715 \\
\hline
\end{tabular}

b. Perhitungan Age Replacement Seal Gp-Duo Cone pada HEX-004

Dengan nilai $\alpha$ sebesar $971,5, \beta$ sebesar 71,3 , MTTF sebesar 965,99, MTTR sama dengan Tf yaitu sebesar 14,71, dan Tp sebesar 2, maka nilai masing-masing $\mathrm{R}(\mathrm{tp}), \mathrm{F}(\mathrm{tp}), \mathrm{M}(\mathrm{tp})$ dan $\mathrm{D}(\mathrm{tp})$ antara lain.

Tabel 21. Age Replacement Seal Gp-Duo Cone HEX-004

\begin{tabular}{ccccc}
\hline tp & $\mathrm{R}(\mathrm{tp})$ & $\mathrm{F}(\mathrm{tp})$ & $\mathrm{M}(\mathrm{tp})$ & $\mathrm{D}(\mathrm{tp})$ \\
\hline 850 & 0,99993 & $7,293 \mathrm{E}-05$ & 13246192,29 & 0,001100663 \\
880 & 0,99914 & $8,645 \mathrm{E}-04$ & 1117423,72 & 0,001088644 \\
881 & 0,99906 & $9,374 \mathrm{E}-04$ & 1030542,67 & 0,001088594 \\
882 & 0,99898 & $1,016 \mathrm{E}-03$ & 950506,91 & 0,001088589 \\
883 & 0,99890 & $1,102 \mathrm{E}-03$ & 876770,26 & 0,001088632 \\
884 & 0,99881 & $1,194 \mathrm{E}-03$ & 808830,64 & 0,001088728 \\
885 & 0,99871 & $1,294 \mathrm{E}-03$ & 746226,50 & 0,001088879 \\
900 & 0,99572 & $4,284 \mathrm{E}-03$ & 225468,41 & 0,001102064 \\
950 & 0,81646 & $1,835 \mathrm{E}-01$ & 5263,09 & 0,002481616 \\
\hline
\end{tabular}

c. Perhitungan Age Replacement Valve Gp-Sol pada HEX-004

Dengan nilai $\alpha$ sebesar $1111, \beta$ sebesar 79,35, MTTF sebesar 1104,70, MTTR sama dengan Tf yaitu sebesar 17,07, dan Tp sebesar 4, maka nilai masing-masing $\mathrm{R}(\mathrm{tp})$, $\mathrm{F}(\mathrm{tp}), \mathrm{M}(\mathrm{tp})$ dan $\mathrm{D}(\mathrm{tp})$ antara lain.

Tabel 22. Age Replacement Valve Gp-Sol pada HEX-004

\begin{tabular}{ccccc}
\hline $\mathrm{tp}$ & $\mathrm{R}(\mathrm{tp})$ & $\mathrm{F}(\mathrm{tp})$ & $\mathrm{M}(\mathrm{tp})$ & $\mathrm{D}(\mathrm{tp})$ \\
\hline 1000 & 0,99976 & 0,00024 & 4684962,71 & 0,001898574 \\
1024 & 0,99845 & 0,00155 & 713985,78 & 0,001886422 \\
1025 & 0,99833 & 0,00167 & 660814,37 & 0,001886414 \\
1026 & 0,99819 & 0,00181 & 611651,91 & 0,001886474 \\
1027 & 0,99805 & 0,00195 & 566192,68 & 0,00188661 \\
1028 & 0,99789 & 0,00211 & 524154,53 & 0,001886826 \\
1050 & 0,98874 & 0,01126 & 98116,15 & 0,001931583 \\
1100 & 0,63505 & 0,36495 & 3027,02 & 0,004839791 \\
1200 & 0,00000 & 1,00000 & 1104,70 & 0,015217023 \\
\hline
\end{tabular}

d. Perhitungan Age Replacement Element-Fuel pada HEX-012

Dengan nilai $\alpha$ sebesar $512,5, \beta$ sebesar 93,22, MTTF sebesar 509,59, MTTR sama dengan Tf yaitu sebesar 11,28, dan Tp sebesar 1, maka nilai masing-masing $R(t p)$, $\mathrm{F}(\mathrm{tp}), \mathrm{M}(\mathrm{tp})$ dan $\mathrm{D}(\mathrm{tp})$ antara lain

Tabel 23. Age Replacement Element-Fuel pada HEX-012

\begin{tabular}{ccccc}
\hline tp & $\mathrm{R}(\mathrm{tp})$ & $\mathrm{F}(\mathrm{tp})$ & $\mathrm{M}(\mathrm{tp})$ & $\mathrm{D}(\mathrm{tp})$ \\
\hline 450 & 0,99999 & $5,430 \mathrm{E}-06$ & 93845635,16 & 0,001041088 \\
471 & 0,99962 & $3,813 \mathrm{E}-04$ & 1336464,05 & 0,001022932 \\
472 & 0,99954 & $4,646 \mathrm{E}-04$ & 1096759,07 & 0,001022803 \\
473 & 0,99943 & $5,659 \mathrm{E}-04$ & 900431,78 & 0,001022871 \\
474 & 0,99931 & $6,890 \mathrm{E}-04$ & 739564,55 & 0,001023177 \\
475 & 0,99916 & $8,386 \mathrm{E}-04$ & 607697,29 & 0,001023772 \\
500 & 0,90477 & $9,523 \mathrm{E}-02$ & 5351,18 & 0,00205296 \\
550 & 0,00000 & $1,000 \mathrm{E}+00$ & 509,59 & 0,021656075 \\
\hline
\end{tabular}


e. Perhitungan Age Replacement Valve Gp-Sol pada HEX-012

Dengan nilai $\alpha$ sebesar 968,2, $\beta$ sebesar 82,28, MTTF sebesar 962,71, MTTR sama dengan Tf sebesar 16,12, dan Tp sebesar 4, maka nilai masing-masing R(tp), F(tp), M(tp) dan $\mathrm{D}(\mathrm{tp})$ antara lain.

Tabel 24. Age Replacement Valve Gp-Sol HEX-012

\begin{tabular}{ccccc}
\hline tp & $\mathrm{R}(\mathrm{tp})$ & $\mathrm{F}(\mathrm{tp})$ & $\mathrm{M}(\mathrm{tp})$ & $\mathrm{D}(\mathrm{tp})$ \\
\hline 850 & 0,99998 & $2,225 \mathrm{E}-05$ & 43263111,44 & 0,002201953 \\
895 & 0,99845 & $1,550 \mathrm{E}-03$ & 620925,75 & 0,002160244 \\
896 & 0,99830 & $1,700 \mathrm{E}-03$ & 566458,89 & 0,002160209 \\
897 & 0,99814 & $1,863 \mathrm{E}-03$ & 516826,43 & 0,002160281 \\
898 & 0,99796 & $2,041 \mathrm{E}-03$ & 471594,58 & 0,002160469 \\
899 & 0,99776 & $2,237 \mathrm{E}-03$ & 430368,91 & 0,002160785 \\
900 & 0,99755 & $2,451 \mathrm{E}-03$ & 392790,71 & 0,00216124 \\
\hline
\end{tabular}

f. Perhitungan Age Replacement Sensor As-Level pada HEX-012

Dengan nilai $\alpha$ sebesar $1257, \beta$ sebesar 74,13, MTTF sebesar 1249,87. MTTR sama dengan Tf yaitu sebesar 11,99, dan Tp sebesar 1, maka nilai masing-masing $R(t p)$, $\mathrm{F}(\mathrm{tp}), \mathrm{M}(\mathrm{tp})$ dan $\mathrm{D}(\mathrm{tp})$ antara lain.

Tabel 25. Age Replacement Sensor As-Level HEX-012

\begin{tabular}{ccccc}
\hline$t \mathrm{p}$ & $\mathrm{R}(\mathrm{tp})$ & $\mathrm{F}(\mathrm{tp})$ & $\mathrm{M}(\mathrm{tp})$ & $\mathrm{D}(\mathrm{tp})$ \\
\hline 1100 & 0,99995 & $5,066 \mathrm{E}-05$ & 24669493,34 & 0,000425621 \\
1135 & 0,99948 & $5,164 \mathrm{E}-04$ & 2420237,18 & 0,000421616 \\
1136 & 0,99945 & $5,513 \mathrm{E}-04$ & 2267320,97 & 0,000421606 \\
1137 & 0,99941 & $5,884 \mathrm{E}-04$ & 2124190,84 & 0,000421608 \\
1138 & 0,99937 & $6,280 \mathrm{E}-04$ & 1990212,72 & 0,000421622 \\
1150 & 0,99863 & $1,366 \mathrm{E}-03$ & 914860,56 & 0,000423044 \\
1200 & 0,96845 & $3,155 \mathrm{E}-02$ & 39611,99 & 0,000558047 \\
1250 & 0,51632 & $4,837 \mathrm{E}-01$ & 2584,11 & 0,003321219 \\
1300 & 0,00001 & $1,000 \mathrm{E}+00$ & 1249,88 & 0,009501744 \\
\hline
\end{tabular}

\section{Klasifikasi Komponen Kritis}

Setelah diketahui nilai MTTR dan MTTF dari tiap komponen kritis maka tiap komponen kritis akan dikalsifikasikan menurut jenis yang dapat diperbaiki (repairable) dan yang tidak dapat diperbaiki (non repairable) sebagai berikut.

Tabel 26. Klasifikasi Komponen Kritis

\begin{tabular}{cccc}
\hline $\begin{array}{c}\text { Mesin } \\
\text { Kritis }\end{array}$ & Komponen Kritis & Kategori & $\begin{array}{c}\text { Harga } \\
\text { Komponen (\$) }\end{array}$ \\
\hline \multirow{2}{*}{ HEX- } & Element-Fuel & Non Repairable & 26,79 \\
004 & Seal Gp-Duo Cone & Non Repairable & 118,31 \\
& Valve Gp-Sol & Non Repairable & 64,02 \\
\hline \multirow{2}{*}{ HEX- } & Element-Fuel & Non Repairable & 26,79 \\
012 & Valve Gp-Sol & Non Repairable & 64,02 \\
& Sensor As-Level & Non Repairable & 50,15 \\
\hline
\end{tabular}

\section{Perhitungan Jumlah Suku Cadang dengan Metode Reliability Centered Spares}

a. Perhitungan jumlah suku cadang non repairable

Berikut contoh perhitungan $\lambda \mathrm{t}$ suku cadang minimum yang harus dipersiapkan per tahun untuk kategori suku cadang non repairable.
Tabel 27. Contoh Perhitungan $\lambda \mathrm{t}$ dari Suku Cadang Non Repairable

\begin{tabular}{ccc}
\hline Field ID & HEX-004 & \\
\hline Suku Cadang & Element-Fuel & \\
\hline MTTF & 515,88 & jam \\
A & 1 & buah \\
P & $95 \%$ & \\
N & 1 & buah \\
T & 12 & bulan \\
M & 600 & jam/bulan \\
$\lambda \mathrm{t}$ & 13,96 & \\
\hline
\end{tabular}

Berikut contoh perhitungan jumlah suku cadang minimum yang harus dipersiapkan per tahun untuk kategori suku cadang non repairable.

Tabel 28. Contoh Perhitungan Jumlah Minimum Suku Cadang Non Repairable

\begin{tabular}{cccccc}
\hline $\mathrm{n}$ & fact(n-1) & $\exp (-\lambda \mathrm{t})$ & $\lambda \mathrm{tn} / \mathrm{n} !$ & $\mathrm{P}$ & $\mathrm{P}(\%)$ \\
\hline 0 & 1 & $8,7 \mathrm{E}-07$ & 1,00 & $8,68 \mathrm{E}-07$ & $0,0 \%$ \\
1 & 1 & $8,7 \mathrm{E}-07$ & 13,96 & $1,30 \mathrm{E}-05$ & $0,0 \%$ \\
2 & 2 & $8,7 \mathrm{E}-07$ & 97,40 & $9,76 \mathrm{E}-05$ & $0,0 \%$ \\
3 & 6 & $8,7 \mathrm{E}-07$ & 453,11 & $4,91 \mathrm{E}-04$ & $0,0 \%$ \\
4 & 24 & $8,7 \mathrm{E}-07$ & 1580,97 & $1,86 \mathrm{E}-03$ & $0,2 \%$ \\
5 & 120 & $8,7 \mathrm{E}-07$ & 4413,04 & $5,70 \mathrm{E}-03$ & $0,6 \%$ \\
6 & 720 & $8,7 \mathrm{E}-07$ & 10265,27 & $1,46 \mathrm{E}-02$ & $1,5 \%$ \\
7 & 5040 & $8,7 \mathrm{E}-07$ & 20467,09 & $3,24 \mathrm{E}-02$ & $3,2 \%$ \\
8 & 40320 & $8,7 \mathrm{E}-07$ & 35706,72 & $6,34 \mathrm{E}-02$ & $6,3 \%$ \\
9 & 362880 & $8,7 \mathrm{E}-07$ & 55372,13 & $1,11 \mathrm{E}-01$ & $11,1 \%$ \\
10 & $3,6 \mathrm{E}+06$ & $8,7 \mathrm{E}-07$ & 77281,41 & $1,79 \mathrm{E}-01$ & $17,9 \%$ \\
11 & $4,0 \mathrm{E}+07$ & $8,7 \mathrm{E}-07$ & 98054,19 & $2,64 \mathrm{E}-01$ & $26,4 \%$ \\
12 & $4,8 \mathrm{E}+08$ & $8,7 \mathrm{E}-07$ & 114043,02 & $3,63 \mathrm{E}-01$ & $36,3 \%$ \\
13 & $6,2 \mathrm{E}+09$ & $8,7 \mathrm{E}-07$ & 122436,01 & $4,69 \mathrm{E}-01$ & $46,9 \%$ \\
14 & $8,7 \mathrm{E}+10$ & $8,7 \mathrm{E}-07$ & 122057,63 & $5,75 \mathrm{E}-01$ & $57,5 \%$ \\
15 & $1,3 \mathrm{E}+12$ & $8,7 \mathrm{E}-07$ & 113568,39 & $6,74 \mathrm{E}-01$ & $67,4 \%$ \\
16 & $2,1 \mathrm{E}+13$ & $8,7 \mathrm{E}-07$ & 99065,24 & $7,60 \mathrm{E}-01$ & $76,0 \%$ \\
17 & $3,6 \mathrm{E}+14$ & $8,7 \mathrm{E}-07$ & 81331,01 & $8,30 \mathrm{E}-01$ & $83,0 \%$ \\
18 & $6,4 \mathrm{E}+15$ & $8,7 \mathrm{E}-07$ & 63061,96 & $8,85 \mathrm{E}-01$ & $88,5 \%$ \\
19 & $1,2 \mathrm{E}+17$ & $8,7 \mathrm{E}-07$ & 46323,11 & $9,25 \mathrm{E}-01$ & $92,5 \%$ \\
20 & $2,4 \mathrm{E}+18$ & $8,7 \mathrm{E}-07$ & 32325,96 & $9,53 \mathrm{E}-01$ & $95,3 \%$ \\
21 & $5,1 \mathrm{E}+19$ & $8,7 \mathrm{E}-07$ & 21484,04 & $9,72 \mathrm{E}-01$ & $97,2 \%$ \\
22 & $1,1 \mathrm{E}+21$ & $8,7 \mathrm{E}-07$ & 13629,41 & $9,84 \mathrm{E}-01$ & $98,4 \%$ \\
\hline & & & & & \\
\hline
\end{tabular}

Dari contoh hasil perhitungan di atas diketahui bahwa jumlah suku cadang minimum yang harus dipersiapkan tiap tahunnya sebanyak 20 unit.

Rekapitulasi kebutuhan suku cadang kritis pada excavator dengan kode HEX-004 selama setahun dengan konversi mata uang sebesar Rp 14.073,80 per tanggal 22 Januari 2021 adalah sebagai berikut

Tabel 29. Rekapitulasi Kebutuhan Suku Cadang Kritis HEX-004

\begin{tabular}{ccccc}
\hline $\begin{array}{c}\text { Suku } \\
\text { Cadang } \\
\text { Kritis }\end{array}$ & $\begin{array}{c}\text { Kebutuhan } \\
\text { Suku Cadang } \\
\text { (Item per } \\
\text { Tahun) }\end{array}$ & $\begin{array}{c}\text { Harga } \\
\text { Satuan } \\
\text { Suku } \\
\text { Cadang }\end{array}$ & $\begin{array}{c}\text { Total } \\
\text { Harga } \\
\text { Suku } \\
\text { Cadang }\end{array}$ & Total (Rp) \\
\hline $\begin{array}{c}\text { Element- } \\
\text { Fuel }\end{array}$ & 20 & 26,79 & 535,80 & $7.540 .742,04$ \\
$\begin{array}{c}\text { Seal Gp- } \\
\text { Duo Cone } \\
\text { Valve Gp- } \\
\text { Sol }\end{array}$ & 12 & 118,31 & $1.419,72$ & $19.980 .855,34$ \\
\hline Total & 11 & 64,02 & 704,22 & $9.911 .051,44$ \\
\hline
\end{tabular}


Rekapitulasi kebutuhan suku cadang kritis pada excavator dengan kode HEX-012 selama setahun dengan konversi mata uang sebesar Rp 14.073,80 per tanggal 22 Januari 2021 adalah sebagai berikut

Tabel 30. Rekapitulasi Kebutuhan Suku Cadang Kritis HEX-012

\begin{tabular}{ccccc}
\hline $\begin{array}{c}\text { Suku } \\
\text { Cadang } \\
\text { Kritis }\end{array}$ & $\begin{array}{c}\text { Kebutuhan } \\
\text { Suku } \\
\text { Cadang } \\
\text { Item per } \\
\text { Tahun) }\end{array}$ & $\begin{array}{c}\text { Harga } \\
\text { Satuan } \\
\text { Suku } \\
\text { Cadang }\end{array}$ & $\begin{array}{c}\text { Total } \\
\text { Harga } \\
\text { Suku } \\
\text { Cadang }\end{array}$ & Total (Rp) \\
\hline $\begin{array}{c}\text { Element- } \\
\text { Fuel }\end{array}$ & 21 & 26,79 & 562,59 & $7.917 .779,14$ \\
$\begin{array}{c}\text { Valve } \\
\text { Gp-Sol } \\
\begin{array}{c}\text { Sensor } \\
\text { As-Level }\end{array}\end{array}$ & 12 & 64,02 & 768,24 & $10.812 .056,11$ \\
\hline Total & 10 & 50,15 & 501,50 & $7.058 .010,70$ \\
\hline
\end{tabular}

\section{Perhitungan Nilai Risk Priority Number}

Nilai Risk Priority Number (RPN) dari tiap mode kegagalan pada sistem dan efek yang ditimbulkan dalam penggantian komponen adalah sebagai berikut.

Tabel 31. Nilai RPN Komponen Kritis

\begin{tabular}{|c|c|c|c|c|c|c|c|}
\hline $\begin{array}{l}\text { Mesin } \\
\text { Kritis }\end{array}$ & $\begin{array}{l}\text { Komponen } \\
\text { Kritis }\end{array}$ & $\begin{array}{c}\text { Kode } \\
\text { FF }\end{array}$ & $\begin{array}{c}\text { Kode } \\
\text { FM }\end{array}$ & $S$ & $\mathrm{O}$ & $\mathrm{D}$ & RPN \\
\hline \multirow{6}{*}{$\begin{array}{c}\text { HEX- } \\
004\end{array}$} & \multirow{2}{*}{$\begin{array}{l}\text { Element- } \\
\text { Fuel }\end{array}$} & \multirow{2}{*}{ A } & 1 & 9 & 9 & 4 & 324 \\
\hline & & & 2 & 7 & 9 & 4 & 252 \\
\hline & \multirow{2}{*}{$\begin{array}{c}\text { Seal Gp- } \\
\text { Duo Cone }\end{array}$} & \multirow{2}{*}{ A } & 1 & 7 & 8 & 8 & 448 \\
\hline & & & 2 & 7 & 8 & 8 & 448 \\
\hline & \multirow{2}{*}{$\begin{array}{l}\text { Valve Gp- } \\
\quad \text { Sol }\end{array}$} & \multirow{2}{*}{ A } & 1 & 8 & 8 & 4 & 256 \\
\hline & & & 2 & 8 & 8 & 4 & 256 \\
\hline \multirow{9}{*}{$\begin{array}{c}\text { HEX- } \\
012\end{array}$} & \multirow{2}{*}{$\begin{array}{l}\text { Element- } \\
\text { Fuel }\end{array}$} & \multirow{2}{*}{ A } & 1 & 9 & 9 & 4 & 324 \\
\hline & & & 2 & 7 & 9 & 4 & 252 \\
\hline & \multirow{2}{*}{$\begin{array}{l}\text { Valve Gp- } \\
\quad \text { Sol }\end{array}$} & \multirow{2}{*}{ A } & 1 & 8 & 8 & 4 & 256 \\
\hline & & & 2 & 8 & 8 & 4 & 256 \\
\hline & \multirow{5}{*}{$\begin{array}{l}\text { Sensor As- } \\
\text { Level }\end{array}$} & \multirow{2}{*}{ A } & 1 & 7 & 8 & 5 & 280 \\
\hline & & & 2 & 7 & 8 & 5 & 280 \\
\hline & & \multirow{2}{*}{ B } & 1 & 7 & 8 & 5 & 280 \\
\hline & & & 2 & 7 & 8 & 5 & 280 \\
\hline & & $\mathrm{C}$ & 1 & 5 & 8 & 5 & 200 \\
\hline
\end{tabular}

Usulan perbaikan berdasarkan hasil perhitungan RPN serta Failure Mode and Effect Analysis adalah pada seal gp-duo cone dengan mengecek oli final drive dengan Scheduled Oil Sampling, element-fuel dengan menjaga kebersihan fuel yang akan diisikan ke tangki bahan bakar sesuai standar ISO4406:2021, serta valve gp-sol dan sensor as-level adalah mengecek active event pada memory Electronic Control Module.

\section{Penyusunan RCM Decision Worksheet}

Dari tabel hasil Failure Mode and Effect Analysis tersebut maka dapat dibuat RCM Decision Worksheet dari excavator dengan kode HEX-004 sebagai berikut.

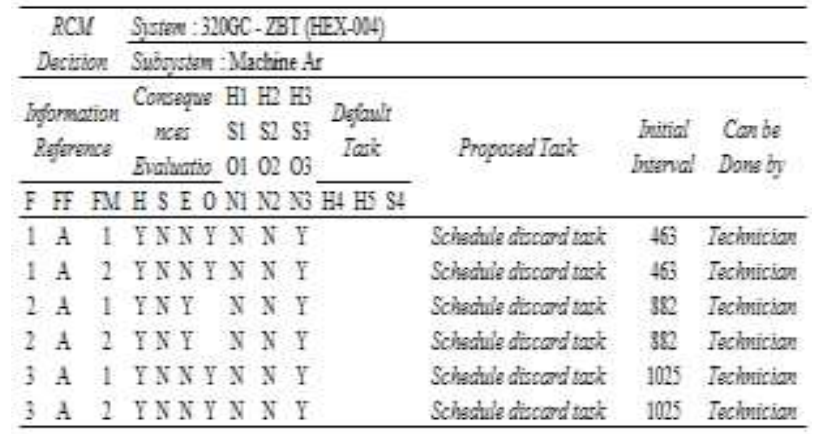

Gambar 4. RCM Decision Worksheet HEX-004

Dari tabel hasil Failure Mode and Effect Analysis tersebut maka dapat dibuat RCM Decision Worksheet dari excavator dengan kode HEX-012 sebagai berikut.

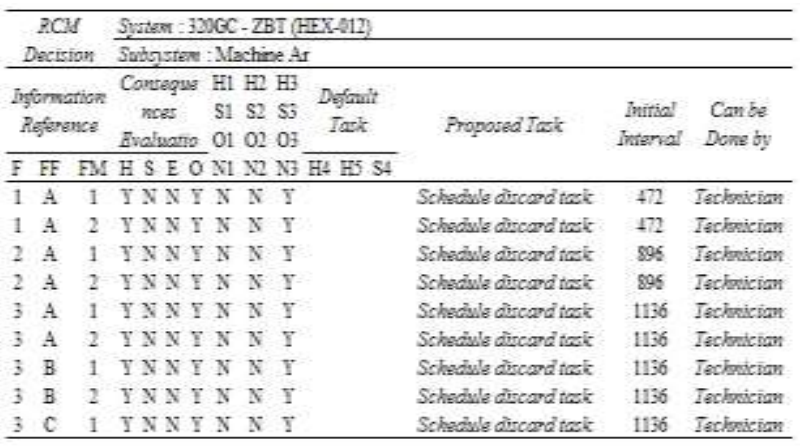

Gambar 5. RCM Decision Worksheet HEX-012

\section{Perhitungan Total Biaya Perawatan}

Dari tabel di atas dapat dihitung biaya perawatan masingmasing suku cadang sebagai berikut.

Tabel 32. Biaya dalam Proses Perawatan

\begin{tabular}{cccc}
\hline $\begin{array}{c}\text { Mesin } \\
\text { Kritis }\end{array}$ & Komponen Kritis & $\mathrm{Cp}(\$)$ & $\mathrm{Cf}(\$)$ \\
\hline \multirow{2}{*}{ HEX- } & Element-Fuel & 70,00 & $28.166,25$ \\
004 & Seal Gp-Duo Cone & 660,39 & $44.538,79$ \\
& Valve Gp-Sol & 118,93 & $51.121,09$ \\
\hline \multirow{2}{*}{ HEX- } & Element-Fuel & 70,00 & $33.788,79$ \\
012 & Valve Gp-Sol & 118,93 & $48.279,92$ \\
& Sensor As-Level & 74,78 & $35.908,76$ \\
\hline & Total & $1.113,03$ & $241.803,60$ \\
\hline
\end{tabular}

Cf adalah biaya perbaikan atau penggatian karena kerusakan komponen, A adalah biaya teknisi per jam, B adalah biaya kerugian produksi (loss revenue) per jam, $\mathrm{C}$ adalah waktu perbaikan kerusakan dalam jam, D adalah biaya pembelian komponen, $\mathrm{Cp}$ adalah biaya yang dikeluarkan untuk pemeliharaan.

Dari tabel 32 diatas maka dapat dihitung nilai penghematan atas strategi perawatan yang selama ini dijalankan perusahaan dibandingkan dengan strategi usulan pada HEX-004 sebagai berikut.

Tabel 33. Penghematan dalam Proses Perawatan HEX-004

\begin{tabular}{cccc}
\hline $\begin{array}{c}\text { Komponen } \\
\text { Kritis }\end{array}$ & $\begin{array}{c}\mathrm{Tc}(\mathrm{tp}) \\
(\mathrm{Rp} / \mathrm{jam})\end{array}$ & $\begin{array}{c}\mathrm{Tc}(\mathrm{tf}) \\
(\mathrm{Rp} / \mathrm{jam})\end{array}$ & $\Delta \mathrm{TC}(\mathrm{Rp})$ \\
\hline $\begin{array}{c}\text { Element-Fuel } \\
\text { Seal Gp-Duo }\end{array}$ & $2.948,18$ & $768.407,82$ & $765.459,64$ \\
$\begin{array}{c}\text { Cone } \\
\text { Valve Gp-Sol }\end{array}$ & $11.248,11$ & $648.899,14$ & $637.651,03$ \\
\hline Total & 1603,30 & $651.279,07$ & $648.475,78$ \\
\hline
\end{tabular}

Dio Aldri 
Dari tabel 32 di atas maka dapat dihitung nilai penghematan atas strategi perawatan yang selama ini dijalankan perusahaan dibandingkan dengan strategi usulan pada HEX-012 sebagai berikut.

Tabel 34. Penghematan dalam Proses Perawatan HEX-012

\begin{tabular}{cccc}
\hline $\begin{array}{c}\text { Komponen } \\
\text { Kritis }\end{array}$ & $\begin{array}{c}\mathrm{Tc}(\mathrm{tp}) \\
(\mathrm{Rp} / \mathrm{jam})\end{array}$ & $\begin{array}{c}\mathrm{Tc}(\mathrm{tf}) \\
(\mathrm{Rp} / \mathrm{jam})\end{array}$ & $\Delta \mathrm{TC}(\mathrm{Rp})$ \\
\hline $\begin{array}{c}\text { Element- } \\
\text { Fuel }\end{array}$ & $2.554,27$ & $933.175,01$ & $930.620,75$ \\
$\begin{array}{c}\text { Valve Gp- } \\
\quad \text { Sol }\end{array}$ & $3.153,34$ & $705.801,20$ & $702.647,86$ \\
$\begin{array}{c}\text { Sensor As- } \\
\text { Level }\end{array}$ & $1.171,10$ & $404.340,25$ & $403.169,15$ \\
\hline Total & $6.878,71$ & $2.043 .316,46$ & $2.036 .437,75$ \\
\hline
\end{tabular}

\section{CONCLUSIONS}

Simpulan dari penelitian ini antara lain strategi perawatan yang tepat sesuai metode Reliability Centered Maintenance adalah schedule discard task. Waktu yang tepat untuk perawatan dan kebutuhan parts per tahun sesuai metode Age Replacement dan Reliability Centered Spares pada HEX-004 adalah element-fuel pada 463 jam dan 20 unit, seal gp-duo cone pada 882 jam dan 12 unit, serta valve gp-sol pada 1025 jam dan 11 unit. Pada HEX-012 elementfuel pada 472 jam dan 21 unit, valve gp-sol pada 896 jam dan 12 unit, serta sensor as-level pada 1136 jam dan 10 unit. Total penghematan dari strategi yang diusulkan sebesar \$ 290,47 atau Rp 4.088.024,21 per jam. Usulan perbaikan pada seal gp-duo cone dengan mengecek oli final drive dengan Scheduled Oil Sampling, element-fuel dengan menjaga kebersihan fuel yang akan diisikan ke tangki bahan bakar sesuai standar ISO4406:2021, serta valve gp-sol dan sensor as-level adalah mengecek active event pada memory Electronic Control Module.

\section{REFERENCES}

[1] Kementerian ESDM, "Capaian Kinerja 2019 dan Program 2020,” 2020.

[2] Bank Indonesia, "Laporan Perekonomian Indonesia 2019," 2020.

[3] F. B. Pradana, "Menangkap Potensi 'Besar' dari Bisnis Alat Berat," Kompasiana.com. 2017, [Online]. Available: https://www.kompasiana.com/farizbagusp/5a35b82ccf0 1b45bad56c404/menangkap-potensi-besar-dari-bisnisalat-berat?page $=$ all.

[4] H. Bhatia, "6.8 Million Connected Heavy Construction Machines to be Shipped till 2025," Counterpoint, 2019.

[5] K. Peng, Equipment Management in the PostMaintenance Era. 2012.

[6] A. Birolini, Reliability Engineering Theory and Practice 8th Edition. 2017.

[7] J. D. Campbell and J. V. Reyes-Picknell, Uptime: Strategies for Excellence in Maintenance Management. 2016.

[8] E. Bradley, Reliability Engineering: A life Cycle Approach. 2017.

[9] B. S. Dhillon, Engineering systems reliability, safety, and maintenance: An integrated approach. 2017.
[10] T. Jin, Reliability Engineering and Services. 2019.

[11] D. Galar, P. Sandborn, and U. Kumar, Maintenance Costs and Life Cycle Cost Analysis. 2017.

[12] S. O. Duffuaa and A. Raouf, Planning and Control of Maintenance Systems. 2015. 